\title{
Comparative Assessment of Trace Elements in the Blood of Gastric Cancer Patients and Healthy Subjects
}

\author{
Annum Afzal ${ }^{1 \mathbb{D}}$, Muhammad Abdul Qayyum 2 ${ }^{\mathbb{D}}$, Munir H. Shah ${ }^{1, *} \mathbb{D}$ \\ 1 Department of Chemistry, Quaid-i-Azam University, Islamabad 45320, Pakistan; anumafzal46@yahoo.com (A.A.); \\ mhshahg@qau.edu.pk (M.H.S.); munir_qau@yahoo.com (M.H.S.); \\ 2 Department of Chemistry, Division of Science \& Technology, University of Education Lahore, Pakistan; hmaqayyum@ue.edu.pk \\ (M.A.Q.); \\ * Correspondence: mhshahg@qau.edu.pk; munir_qau@yahoo.com;
}

Scopus Author ID 7402047245

Received: 26.09.2020; Revised: 5.11.2020; Accepted: 10.11.2020; Published: 15.11.2020

\begin{abstract}
Gastric cancer (GC) remains one of the most common malignancies globally, particularly in developing countries. Environmental contaminants such as trace elements are known to involve in a plethora of diseases, including cancer. The present study was carried out to find out the imbalances in trace elemental levels $(\mathrm{Cd}, \mathrm{Cr}, \mathrm{Cu}, \mathrm{Fe}, \mathrm{Mn}, \mathrm{Pb}$, and $\mathrm{Zn})$ in the blood of $\mathrm{GC}$ patients in comparison with and healthy donors. The blood samples were digested in a nitric acid-perchloric acid mixture. The elemental levels were quantified by flame atomic absorption spectrometry. Significantly lower concentrations of zinc, iron, lead, cadmium, and chromium were found in the blood of GC patients than the controls. A correlation study revealed diverse relationships among the elements in the blood of cancerous patients and controls. Considerable variations in the elemental concentrations were observed with the gender, food habits, habitat, and smoking habits of the donors. Elemental contents revealed significant differences with the stages (I, II, III \& IV) and types (adenocarcinoma \& gastrointestinal stromal tumor) of GC patients. Multivariate analysis exhibited significantly divergent apportionment of the patients' elemental levels and healthy subjects, which may be linked with the altered metabolism of the elements in GC patients.
\end{abstract}

Keywords: gastric cancer; trace element; blood; AAS; statistical analysis; Pakistan.

(C) 2020 by the authors. This article is an open-access article distributed under the terms and conditions of the Creative Commons Attribution (CC BY) license (https://creativecommons.org/licenses/by/4.0/).

\section{Introduction}

Living systems often interact with a variety of pollutants in the environment via contaminated air, water, and soil; many metals pollutants can exhibit adverse effects on health that may cause various diseases, including cancer, even at relatively low quantities $[1,2]$. Gastric cancer (GC) is a stomach malignancy, and it remains a common disease worldwide [1]. It begins in the inner layers of the stomach. It moves into the deeper layers over time, eventually reaching the outermost layer and then spreading to other organs such as the liver, pancreas, esophagus, and intestine [3]. Stomach cancer is the $5^{\text {th }}$ most common cancer type and the

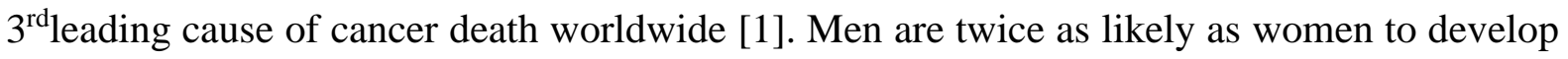
GC, which is more common in elderly subjects [3]. Over $70 \%$ of incident cases and deaths occur in developing countries [4]. Although a relatively lower incidence is reported in Pakistan, the mortality rate due to stomach cancer appears to be high (13.3\%) [5]. GC is a heterogeneous disease with many histopathological types, including adenocarcinoma, lymphoma, gastrointestinal stromal tumor, and carcinoid tumor, etc., [6]. More than 95\% of gastric 
carcinoma are adenocarcinomas, with primary gastric lymphoma being the second most common malignancy [7]. Prognosis in patients with GC is dependent on the stage at which diagnosis is made. The stage also depicts the extent of cancer and how best to treat it [8]. Several studies have investigated the potential risk factors of gastric carcinoma; by far, helicobacter pylori infection is strongly implicated in the etiology of stomach cancer, while other established risk factors for GC include tobacco use, alcoholic drinks, Epstein-Barr virus, high fat, obesity, high salt, radiations, family history, nitrate and nitrite ingestion and occupation exposure to various types of dust [1,9-11]. Dietary factors (i.e., low intakes of fruit and vegetables), exposure to metals, and low income/levels of education in third world countries, especially in Pakistan, are also associated with gastric malignancy [12]. Among all gastric carcinoma risk factors, elements, such as $\mathrm{Cr}, \mathrm{Cd}$, and $\mathrm{Pb}$, are classified as certain/probable carcinogens by the International Agency for Research on Cancer (IARC), revealing that exposure may increase GC risk [13-15].

Quantification of trace elements in blood has become a flourishing field, particularly after knowing the significance of body elemental imbalances in the diagnosis and prevalence of various diseases $[13,16-18]$. Blood is the transport medium for the macronutrients and micronutrients to and from the tissues, giving rapid and reliable information about the metabolism [2]. It provides evidence about what the body has recently absorbed, and ease of sampling is also an extra advantage of blood sampling [19]. Little is known about beneficial or harmful relationships between blood metals levels and GC patients [2]. Altered profiles of elements have been pointed out in various populations of gastric carcinoma patients $[2,18]$. Moreover, no study has yet obtained a reliable estimate of elemental concentrations in Pakistani gastric carcinoma patients' blood. Therefore, this study aimed to investigate the blood concentrations of trace elements ( $\mathrm{Mn}, \mathrm{Cu}, \mathrm{Zn}, \mathrm{Fe}, \mathrm{Pb}, \mathrm{Cr}$, and $\mathrm{Cd}$ ) in the Pakistani population with gastric cancer and to compare these values with matching healthy persons (not infected with malignancy). Comparative distribution, mutual correlations, and multivariate apportionment of the elements in blood samples of gastric carcinoma patients and healthy subjects were also assessed. Variations in the elemental levels in GC patients concerning the types and stages were also evaluated. The study would also help scrutinize the possible role of trace elements in the initiation and development of gastric malignancy in the Pakistani population.

\section{Materials and Methods}

\subsection{Study design and subjects.}

A total of the ninety-nine (99) newly diagnosed stomach cancer patients (54 men and 45 women) admitted in (i) Pakistan Institute of Medical Sciences (PIMS), Islamabad and (ii) Nuclear Oncology \& Radiotherapy Institute (NORI) Islamabad, Pakistan and 96 healthy subjects (60 men and 36 women) were included in the present study on a volunteer basis. The study received prior approval from the Ethical Review Boards of both institutes (NORI and PIMS Islamabad, Pakistan). Participants were given a brief description of the goals, the study's procedure, and written informed consent were acquired from all participants before taking part in the study. Cases of gastric cancer were identified and confirmed by gastric endoscopy and histology. Further, clinicopathological features of the patients were obtained from their medical records. The inclusion criteria were; a) pathologically confirmed newly diagnosis of gastric cancer patients; b) no blood transfusion and no use of mineral supplements for the last six 
months; c) no prior radiotherapy/chemotherapy or anti-neoplastic treatment and no clinical or biochemical evidence of other complications; d) could understand and answer the questions. The exclusion criteria were any one of the following: a) individuals who had taken mineral supplements during the previous six months; b) alcohol consumption; c) unaware of suffering from any malignancy and chemotherapy; d) were diagnosed with chronic wasting diseases (e.g., hepatic diseases, kidney diseases, diabetes mellitus, and cancers), or were pregnant (female) any type of gastric surgery. Healthy donors were also included on a volunteer basis with matched age groups and similar socioeconomic status. In many cases, healthy donors were either family members or a closely related person to the cancerous patient. The control subjects were in good health, as determined by a medical history questionnaire, physical examination, and normal results of clinical laboratory tests. None of the control subjects were taking any medication. Information on socio-demographics, tobacco use, nutritional habits, habitat, income, and educational level was obtained by a questionnaire administered by interviewers and undertaken face-to-face.

"All subjects gave their informed consent for inclusion before they participated in the study. The study was conducted following the Declaration of Helsinki, and the Ethics Committee approved the protocol of the Pakistan Institute of Medical Sciences (PIMS), Islamabad, and Nuclear Oncology \& Radiotherapy Institute (NORI) Islamabad, Pakistan (QAUC/2015/A153-08).”

\subsection{Sample collection and preparation.}

In the present study, peripheral venous blood samples (approximately $5 \mathrm{~mL}$ ) were collected through the antecubital vein from each subject using the venipuncture procedure. The blood samples were instantly transferred to the evacuated polyethylene tubes without any anticoagulant at room temperature. The blood was drawn before any therapeutic intervention, including surgery, radiotherapy, or chemotherapy in the patients' group. The samples were preserved in a refrigerator at $-20^{\circ} \mathrm{C}$ before the analyses. For the digestion of blood samples, an exactly known amount of blood sample was transferred from the storage tube to the digestion flask. The samples were digested employing nitric acid $\left(\mathrm{HNO}_{3}\right)$ and perchloric acid $\left(\mathrm{HClO}_{4}\right)$ $(10: 1 \mathrm{v} / \mathrm{v})$ mixture with subsequent heating on a hot plate $\left(80-90^{\circ} \mathrm{C}\right)$ to a soft boil until dense white fumes evolved, which marked the completion of the digestion process and clear/transparent solution was obtained. Samples were then cooled to room temperature and diluted to proper volume with doubly distilled water [19]. Blanks containing all the reagents in the same sequence (without blood sample) were also processed with each sample batch.

\subsection{Quantification of trace elements.}

Selected trace elements, including $\mathrm{Cd}, \mathrm{Cr}, \mathrm{Cu}, \mathrm{Fe}, \mathrm{Pb}, \mathrm{Mn}$, and $\mathrm{Zn}$, were quantified in the digested blood samples using a flame atomic absorption spectrophotometer (Shimadzu AA670, Japan) with automatic background compensation under optimum analytical conditions, which are shown in Table 1. Three sub-samples of each sample were used and run separately onto the spectrophotometer to pool the average metal levels. Standard reference material (Animal Serum, NIST SRM 1598a) was routinely used for quality assurance and accuracy. These results showed excellent agreement and excellent recoveries, as presented in Table 1. For comparison of the data, some samples were also analyzed at an independent laboratory. The two results showed very good matching with a maximum of $5 \%$ difference. All reagents 
used during the present study were of ultrahigh purity (certified $>99.99 \%$ ). Working standard solutions of the metals were prepared by serial dilution of $1000 \mathrm{mg} / \mathrm{L}$ stock standard solution just before analyzing the metals on the instrument [19]. The blanks' contribution was generally less than $10 \%$ of the estimated metal levels in the samples. All measurements were made in triplicate.

Table 1. Optimum analytical conditions for the analyses of selected trace elements along with their detection/quantification limits and certified Vs. measured ( \pm SD) levels* ( $\mu \mathrm{g} / \mathrm{g})$ of the elements in SRM.

\begin{tabular}{|c|c|c|c|c|c|c|c|}
\hline \multirow[b]{2}{*}{ Element } & \multirow[b]{2}{*}{$\begin{array}{l}\text { Wavelength } \\
\text { (nm) }\end{array}$} & \multirow{2}{*}{$\begin{array}{l}\text { Slit } \\
\text { width } \\
(\mathbf{n m})\end{array}$} & \multirow{2}{*}{$\begin{array}{l}\text { Limit of } \\
\text { Detection } \\
(\mathrm{mg} / \mathrm{L})\end{array}$} & \multirow{2}{*}{$\begin{array}{l}\text { Limit of } \\
\text { Quantification } \\
\text { (mg/L) }\end{array}$} & \multicolumn{3}{|c|}{ Animal Serum, NIST SRM 1598a } \\
\hline & & & & & $\begin{array}{l}\text { Certified } \\
\text { Level }\end{array}$ & $\begin{array}{l}\text { Measured } \\
\text { Level }\end{array}$ & $\begin{array}{l}\text { Recovery } \\
(\%)\end{array}$ \\
\hline $\mathrm{Fe}$ & 248.3 & 0.2 & 0.006 & 0.018 & 71.2 & $71.60 \pm 1.719$ & 100.6 \\
\hline $\mathrm{Zn}$ & 213.9 & 0.5 & 0.002 & 0.006 & 142 & $143.5 \pm 3.081$ & 101.1 \\
\hline $\mathrm{Cu}$ & 324.8 & 0.5 & 0.004 & 0.013 & 2.4 & $2.387 \pm 0.051$ & 99.5 \\
\hline $\mathrm{Cd}$ & 228.8 & 0.3 & 0.004 & 0.013 & 0.013 & $0.013 \pm 0.002$ & 100.6 \\
\hline $\mathrm{Mn}$ & 279.5 & 0.4 & 0.003 & 0.01 & 0.37 & $0.361 \pm 0.023$ & 97.6 \\
\hline $\mathrm{Pb}$ & 217 & 0.3 & 0.01 & 0.029 & 0.38 & $0.372 \pm 0.019$ & 97.9 \\
\hline $\mathrm{Cr}$ & 357.9 & 0.5 & 0.006 & 0.018 & 0.071 & $0.070 \pm 0.003$ & 98.6 \\
\hline
\end{tabular}

\subsection{Statistical analysis.}

In order to categorize the association among the measured variables, statistical analyses were applied to the metals data by STATISTICA software [20]. Descriptive analysis was conducted to obtain range, means, median, standard deviation (SD), standard error (SE), skewness, and kurtosis. Two-sample t-tests further analyzed the data for comparison of the individual metal levels. Wilcoxon rank-sum test was also used for the comparison of median metal levels between various groups. Pearson correlation analysis was used to investigate the mutual relationships among metal levels. Multivariate analyses in terms of principal component analysis (PCA) and cluster analysis (CA) were employed for apportionment of the metals in the patients and healthy subjects [21]. PCA was performed to obtain quantitative data reflecting the similarities or differences between donor groups as well as variables [22]. CA involves grouping the variables into clusters, each of which is a combination of objects with similar characteristics, resulting in internal homogeneity and external heterogeneity [21].

\section{Results and Discussion}

\subsection{Characteristics of the subjects.}

The demographic parameters related to the gastric cancer patients and healthy subjects are shown in Table 2. The diagnosis of GC was confirmed by histopathological and clinical examinations of the patients. The age of stomach cancer patients ranged from 17 to 63 years (mean value of 45 years), while for healthy subjects, it ranged from 15 to 65 years (mean value of 42 years). , The majority of the participants (> 50\%) in both groups were vegetarians in their food habits, and $63 \%$ of the patients and $60 \%$ of the healthy subjects were inhabiting the rural areas. More than half (> 50\%) of the cancerous patients and healthy subjects were not addicted to tobacco in any form (cigarette smoking, hookah, naswar and chewing paan, etc.). Tumors in patients' stomachs were classified according to their predominant histological pattern into adenocarcinoma $(n=60)$ and gastrointestinal stromal tumors $(n=39)$. According to the newly revised classification of the American Joint Committee on Cancer and the International Union against Cancer [23], the pathologic stage was determined. Thirty-two percent (32\%) of patients have diagnosed with stage II tumors, and $25 \%$ were diagnosed at Stage I tumors in gastric 
cancer patients. Among the remaining patients, $23 \%$ were diagnosed at stage III, while $20 \%$ of patients were diagnosed at stage IV of GC patients, as shown in Table 2. Overall, the cancer patients and healthy subjects closely matched their age, gender, habitat, and food habits.

Table 2. Characteristics of the donor subjects included in the present study.

\begin{tabular}{|c|c|c|}
\hline Parameters & Cancerous Patients & Healthy Subjects \\
\hline$n$ & 99 & 96 \\
\hline \multicolumn{3}{|l|}{ Age (years) } \\
\hline Range (Mean) & $17-63(45)$ & $15-65(42)$ \\
\hline \multicolumn{3}{|l|}{ Gender } \\
\hline Female & $45(45 \%)$ & $36(38 \%)$ \\
\hline Male & $54(55 \%)$ & $60(62 \%)$ \\
\hline \multicolumn{3}{|l|}{ Diet } \\
\hline Vegetarian & $61(62 \%)$ & $51(53 \%)$ \\
\hline Non-vegetarian & $38(38 \%)$ & $45(47 \%)$ \\
\hline \multicolumn{3}{|l|}{ Habitat } \\
\hline Urban & $37(37 \%)$ & $38(40 \%)$ \\
\hline Rural & $62(63 \%)$ & $58(60 \%)$ \\
\hline \multicolumn{3}{|l|}{ Tobacco Use (Smoking) } \\
\hline No use & $57(58 \%)$ & $60(62 \%)$ \\
\hline Use & $42(42 \%)$ & $36(38 \%)$ \\
\hline \multicolumn{3}{|l|}{ Types of Gastric Cancer } \\
\hline Adenocarcinoma & $60(61 \%)$ & -- \\
\hline Gastrointestinal stromal tumor & $39(39 \%)$ & -- \\
\hline \multicolumn{3}{|l|}{ Pathological Stage } \\
\hline Stage-I & $25(25 \%)$ & -- \\
\hline Stage-II & $31(32 \%)$ & -- \\
\hline Stage-III & $23(23 \%)$ & -- \\
\hline Stage-IV & $20(20 \%)$ & -- \\
\hline
\end{tabular}

Table 3. Statistical distribution for the concentrations $(\mu \mathrm{g} / \mathrm{g})$ of selected trace elements in the blood samples of

\begin{tabular}{|c|c|c|c|c|c|c|c|c|}
\hline & & Cd & $\mathrm{Cr}$ & $\mathrm{Cu}$ & $\mathbf{F e}$ & Mn & $\mathbf{P b}$ & $\mathbf{Z n}$ \\
\hline \multirow[t]{8}{*}{ GC Patients } & Min & 0.019 & 0.041 & 0.232 & 192.5 & 0.071 & 0.114 & 1.780 \\
\hline & Max & 1.284 & 11.45 & 2.978 & 492.2 & 5.593 & 17.15 & 24.46 \\
\hline & Mean & 0.274 & 3.263 & 1.316 & 325.1 & 1.745 & 4.307 & 8.685 \\
\hline & Median & 0.193 & 2.679 & 1.174 & 319.4 & 1.413 & 3.364 & 8.264 \\
\hline & SD & 0.274 & 2.549 & 0.700 & 52.58 & 1.373 & 3.774 & 4.517 \\
\hline & SE & 0.049 & 0.393 & 0.104 & 7.437 & 0.214 & 0.629 & 0.666 \\
\hline & Kurtosis & 5.780 & 1.326 & -0.154 & 1.200 & 0.285 & 4.689 & 2.497 \\
\hline & Skewness & 2.213 & 1.126 & 0.701 & 0.366 & 1.047 & 2.047 & 1.331 \\
\hline \multirow[t]{8}{*}{ Healthy Subjects } & Min & 0.133 & 0.027 & 0.012 & 50.63 & 0.202 & 0.243 & 4.640 \\
\hline & Max & 1.183 & 17.68 & 6.228 & $\begin{array}{l}558.8 \\
\end{array}$ & 9.760 & 24.78 & 39.72 \\
\hline & Mean & 0.505 & 6.322 & 1.349 & 326.8 & 2.893 & 8.730 & 12.42 \\
\hline & Median & 0.469 & 6.044 & 1.016 & 347.4 & 2.520 & 6.203 & 10.48 \\
\hline & SD & 0.316 & 3.517 & 1.149 & 123.0 & 2.256 & 7.204 & 7.146 \\
\hline & SE & 0.067 & 0.632 & 0.177 & 18.55 & 0.366 & 1.386 & 1.077 \\
\hline & Kurtosis & 0.346 & 2.589 & 6.970 & 0.002 & 1.335 & -0.427 & 4.410 \\
\hline & Skewness & 0.997 & 0.790 & 2.134 & -0.466 & 1.138 & 0.715 & 1.891 \\
\hline
\end{tabular}

\subsection{Distribution of trace elements.}

The basic statistical parameters related to the distribution of selected elemental levels ( $\mu \mathrm{g} / \mathrm{g}$, wet weight) in blood samples of gastric carcinoma patients are displayed in Table 3. On the mean basis, the highest concentration was observed for iron $(325.1 \mu \mathrm{g} / \mathrm{g})$, followed by a comparatively lower level of zinc $(8.685 \mu \mathrm{g} / \mathrm{g})$, lead $(4.307 \mu \mathrm{g} / \mathrm{g})$, and chromium $(3.263 \mu \mathrm{g} / \mathrm{g})$. In addition, relatively lower average levels were found for manganese $(1.745 \mu \mathrm{g} / \mathrm{g})$, copper $(1.316 \mu \mathrm{g} / \mathrm{g})$, and cadmium $(0.274 \mu \mathrm{g} / \mathrm{g})$. Overall, the average concentrations of metals showed following decreasing order: iron $>$ zinc $>$ lead $>$ chromium $>$ manganese $>$ copper $>$ cadmium. Most of the elements exhibited a large spread in their concentrations, as revealed by their minimum/maximum contents and mean/median levels. A predominantly random distribution 
pattern was shown by most of the elements ( $\mathrm{Fe}, \mathrm{Zn}, \mathrm{Pb}$, and $\mathrm{Cr}$ ), as demonstrated by relatively higher SE and SD values. However, the rest of the metals revealed lesser dispersion in their concentrations. In addition, large skewness/kurtosis values for $\mathrm{Cd}, \mathrm{Pb}$, and $\mathrm{Zn}$ revealed their significant asymmetric distribution. In contrast, lower values for $\mathrm{Cu}$ and $\mathrm{Fe}$ demonstrated the moderately symmetrical distribution of the patients' metals blood. The quartile distribution of selected trace elements in gastric carcinoma blood is shown as a box-whisker plots in Figure 1(a). Most of the elements revealed broad distribution and varying levels except Fe, which indicated a narrow range and small variations in the patients' blood samples. In addition, maximum spread and inconsistent variations of the elemental contents were found for $\mathrm{Cr}$, followed by $\mathrm{Pb}, \mathrm{Cd}$, and $\mathrm{Mn}$. Nevertheless, $\mathrm{Cu}$ and $\mathrm{Zn}$ exhibited approximately comparable broad variations in the quartile distribution in the patients' blood samples.

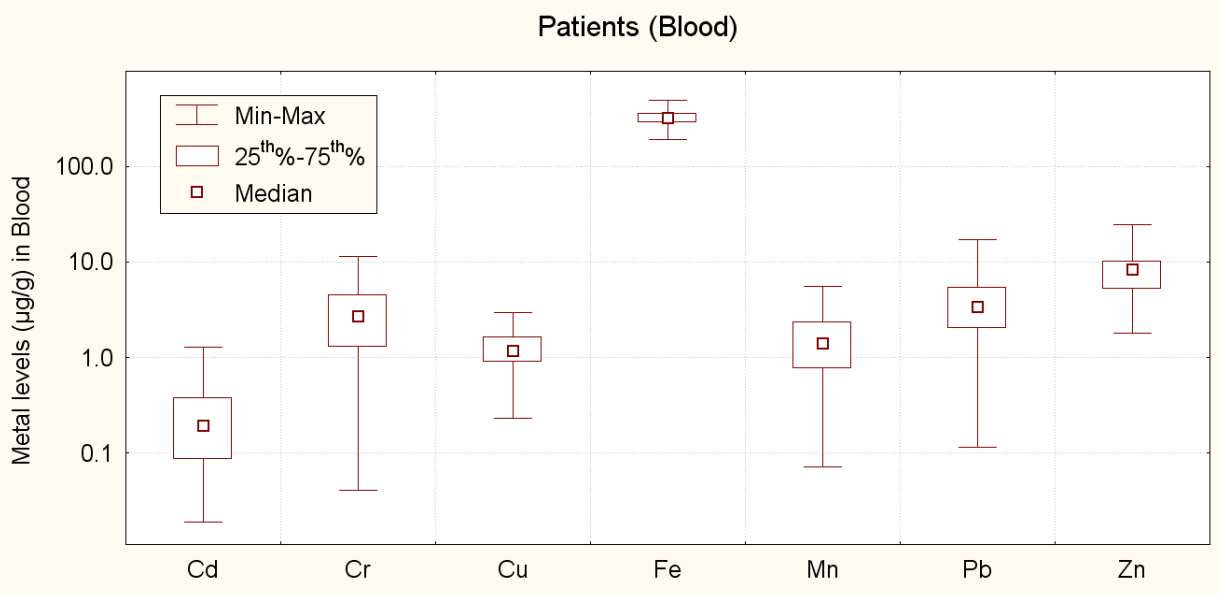

(a)

Controls (Blood)

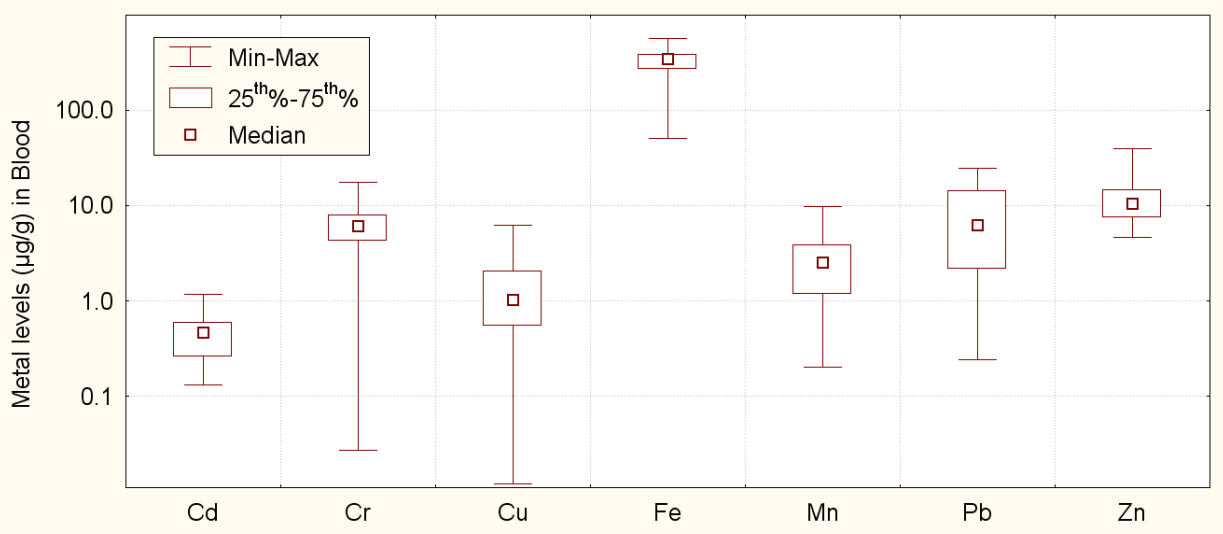

(b)

Figure 1. Quartile distribution of trace elemental levels $(\mu \mathrm{g} / \mathrm{g})$ in the blood samples of (a) gastric cancer patients; (b) healthy subjects.

In the case of healthy subjects, on the average basis, significantly higher concentrations were observed for iron $(326.8 \mu \mathrm{g} / \mathrm{g})$, followed by relatively lower levels of zinc $(12.42 \mu \mathrm{g} / \mathrm{g})$, lead $(8.730 \mu \mathrm{g} / \mathrm{g})$, chromium $(6.322 \mu \mathrm{g} / \mathrm{g})$, while manganese $(2.893 \mu \mathrm{g} / \mathrm{g})$, copper $(1.349 \mu \mathrm{g} / \mathrm{g})$, and cadmium $(0.505 \mu \mathrm{g} / \mathrm{g})$ were estimated at the lowest levels (Table 3). The trace elements in the blood of healthy donors showed following decreasing order in their average concentrations: iron > zinc > lead > chromium > manganese > copper > cadmium. Among the trace elements, $\mathrm{Cd}$ and $\mathrm{Cu}$ exhibited a relatively narrow distribution pattern supported by lower SE and SD values. At the same time, $\mathrm{Fe}, \mathrm{Pb}$, and $\mathrm{Zn}$ demonstrated higher dispersions, as shown by elevated 
$\mathrm{SD}$ and $\mathrm{SE}$ values. Some of the elements $(\mathrm{Pb}, \mathrm{Cd}$, and $\mathrm{Fe})$ revealed symmetrical distribution as indicated by the lowest skewness and kurtosis values. Large skewness values for $\mathrm{Cu}$ and $\mathrm{Zn}$ confirmed their predominantly asymmetrical distribution in the blood of healthy subjects (Table 3). The quartile distribution of trace elements in healthy donors' blood is shown in Figure $1(\mathrm{~b})$, which revealed a relatively narrow distribution of $\mathrm{Cd}, \mathrm{Fe}$, and $\mathrm{Zn}$. However, the rest of the elements exhibited broad and symmetrical distributions in the blood of healthy donors. Compared with the patients, the quartile distribution of the elements in the blood of healthy subjects was considerably divergent.

The average concentrations of trace elements in GC patients' blood and healthy donors are also compared, as shown in Figure 2. Two-tailed students' t-test of the data revealed that the measured concentrations of $\mathrm{Cr}, \mathrm{Cd}, \mathrm{Mn}, \mathrm{Pb}$, and $\mathrm{Zn}$ were significantly $(\mathrm{p}<0.05)$ higher in the blood healthy donors than the cancerous patients. Nevertheless, the estimated $\mathrm{Fe}$ and $\mathrm{Cu}$ levels were observed to be almost comparable in the blood of both donor groups (Figure 2). Similarly, median levels of the trace elements were also compared by the Wilcoxon-rank sum test, which revealed statistically significant differences $(p<0.05)$ for $\mathrm{Mn}, \mathrm{Pb}, \mathrm{Cd}$, and $\mathrm{Cr}$ in the blood of two donor groups; healthy donors exhibited significantly elevated levels than the patients (Table 3).

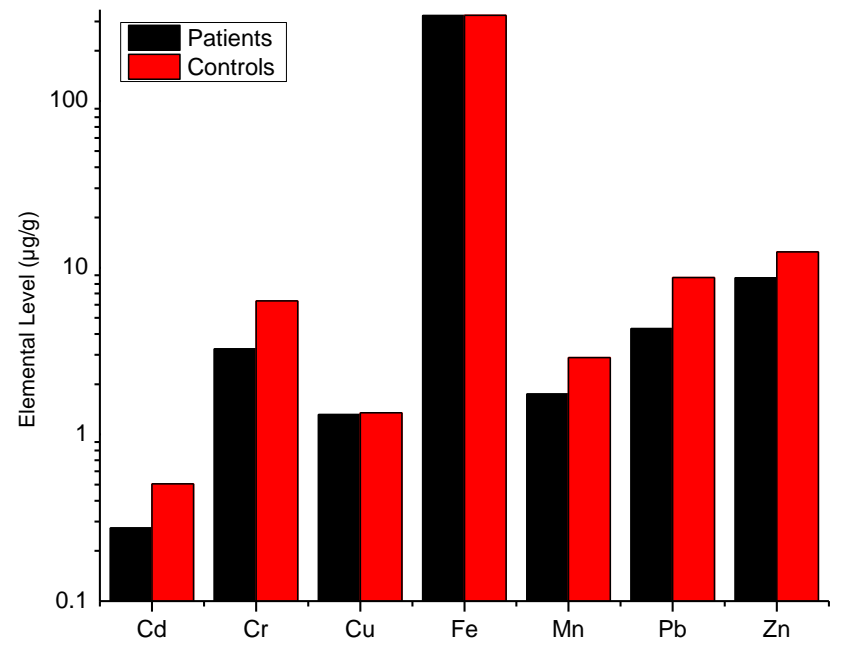

Figure 2. Comparative average concentrations of selected trace elements in the blood samples of gastric cancer patients and healthy subjects.

\subsection{Correlation study.}

The data on element-to-element correlations in GC patients' blood and healthy donors are shown in Table 4, wherein the bold $r$-values are significant at $p<0.05$. In the case of patients, only $\mathrm{Mn}-\mathrm{Cu}(r=0.788)$ showed a solid positive correlation among the trace elements. However, some statistically significant correlations were observed for $\mathrm{Pb}-\mathrm{Mn}(r=0.379)$ and $\mathrm{Cr}-\mathrm{Cd}(r=0.408)$. The rest of the elementals exhibited either weak positive or negative relationships, which were non-significant. No significant relationship was observed for Fe and $\mathrm{Zn}$ with any other element, thus indicating their independent distribution/variations in the patients' blood. The correlation study indicated mostly independent variations for most elemental pairs as significant mutual correlations were noted among few trace elements in the blood of gastric cancerous patients; consequently, the correlation study demonstrated the disproportional distribution of trace elements in GC patients. 
In the case of healthy donors (Table 4), significantly strong positive correlation was observed for $\mathrm{Mn}-\mathrm{Cu}(r=0.682)$; in addition some significant correlations were observed between $\mathrm{Zn}-\mathrm{Mn}(r=0.499), \mathrm{Pb}-\mathrm{Cr}(r=0.459), \mathrm{Zn}-\mathrm{Fe}(r=0.434)$ and $\mathrm{Mn}-\mathrm{Cr}(r=0.381)$. Some pairs, such as Fe-Cd $(r=-0.453)$ and $\mathrm{Zn}-\mathrm{Pb}(r=-0.394)$, exhibited inverse relationships and opposing distributions in the blood of healthy donors. Such inverse relationships indicated the depletion or enrichment of specific elements at the cost of others; in this case, toxic elements $(\mathrm{Cd}$ and $\mathrm{Pb})$ exhibited opposing distribution to those of essential elements (Fe and $\mathrm{Zn}$ ). Overall, the correlation pattern of the trace elements in the blood of GC patients remained noticeably diverse compared with the healthy donors, which may be attributed to the disproportions of the nutrients and trace elements in the gastric tumor patients in comparison with healthy subjects.

Table 4. Correlation coefficient $(r)^{*}$ matrix for selected trace elements in the blood samples of gastric cancer patients (below the diagonal) and healthy subjects (above the diagonal).

\begin{tabular}{l|c|c|c|c|c|c|c} 
& $\mathbf{C d}$ & $\mathbf{C r}$ & $\mathbf{C u}$ & $\mathbf{F e}$ & $\mathbf{M n}$ & $\mathbf{P b}$ & $\mathbf{Z n}$ \\
\hline $\mathrm{Cd}$ & 1 & -0.344 & 0.243 & $\mathbf{- 0 . 4 5 3}$ & 0.087 & -0.171 & -0.144 \\
\hline $\mathrm{Cr}$ & $\mathbf{0 . 4 0 8}$ & 1 & 0.169 & 0.235 & $\mathbf{0 . 3 8 1}$ & $\mathbf{0 . 4 5 9}$ & 0.159 \\
\hline $\mathrm{Cu}$ & -0.217 & -0.279 & 1 & 0.001 & $\mathbf{0 . 6 8 2}$ & -0.063 & 0.071 \\
\hline $\mathrm{Fe}$ & -0.278 & -0.070 & -0.231 & 1 & 0.346 & -0.145 & $\mathbf{0 . 4 3 4}$ \\
\hline $\mathrm{Mn}$ & -0.095 & -0.277 & $\mathbf{0 . 7 8 8}$ & -0.133 & 1 & -0.019 & $\mathbf{0 . 4 9 9}$ \\
\hline $\mathrm{Pb}$ & 0.317 & -0.319 & 0.306 & 0.265 & $\mathbf{0 . 3 7 9}$ & 1 & $\mathbf{- 0 . 3 9 4}$ \\
\hline $\mathrm{Zn}$ & -0.031 & 0.256 & -0.060 & -0.136 & 0.232 & -0.113 & 1
\end{tabular}

*bold $r$-values are significant at $p<0.05$.

\subsection{Comparison based on demographic characteristics.}

Globally GC is generally considered a more common neoplasm in men than women [24]. Accordingly, in the present study, it was noted that gastric tumor is more prevalent in males $(55 \%)$ than in female donors. Gender-based variations in the mean concentrations of trace elements in the blood of gastric cancer patients and healthy donors are shown in Figure 3(a). The comparison revealed a considerably elevated average concentration of $\mathrm{Cd}, \mathrm{Cu}$, and $\mathrm{Pb}$ in male patients than female patients. In contrast, average levels of $\mathrm{Zn}$ and $\mathrm{Mn}$ were found relatively higher in the female gastric carcinoma patients. The prevalence of gastric malignancy was found about twofold higher in males than females [7]. In the case of controls, mean $\mathrm{Pb}$ and $\mathrm{Cd}$ contents revealed higher levels in healthy female donors than male donors. In contrast, the average contents of $\mathrm{Cr}, \mathrm{Fe}, \mathrm{Mn}, \mathrm{Zn}$, and $\mathrm{Cr}$ were observed to be relatively higher in healthy male donors. Nonetheless, mean $\mathrm{Pb}, \mathrm{Cr}$, and $\mathrm{Cd}$ concentrations were found markedly higher in healthy subjects (male $\&$ female) than the cancer subjects (men $\&$ women).

Food and nutrition play a vital role in preventing and incidence of gastric cancer. However, the specific dietary components involved remain unclear [10, 25]. Generally, trace elements enter into the body through foodstuffs, the environment, and water. The stomach is in direct contact with ingested trace elements because of its anatomic position. Many studies have been carried out on the associations between various dietary constituents and GC [26]. A comparison of average elemental levels in the blood based on two donor groups' food-habits is depicted in Figure 3(b), which showed that mean concentrations of $\mathrm{Cu}, \mathrm{Mn}$, and $\mathrm{Pb}$ were found highest in vegetarian patients than non-vegetarian patients. The mean levels of $\mathrm{Cd}, \mathrm{Cr}, \mathrm{Fe}$, and $\mathrm{Zn}$ in the blood of vegetarian and non-vegetarian patients were approximately comparable. In the case of controls, mean levels of $\mathrm{Cr}, \mathrm{Fe}, \mathrm{Zn}$, and $\mathrm{Pb}$ were observed to be higher in the blood of non-vegetarian healthy donors than vegetarian donors. In contrast, the average concentration of $\mathrm{Zn}$ was highest in the blood of controls with vegetarian food habits. 


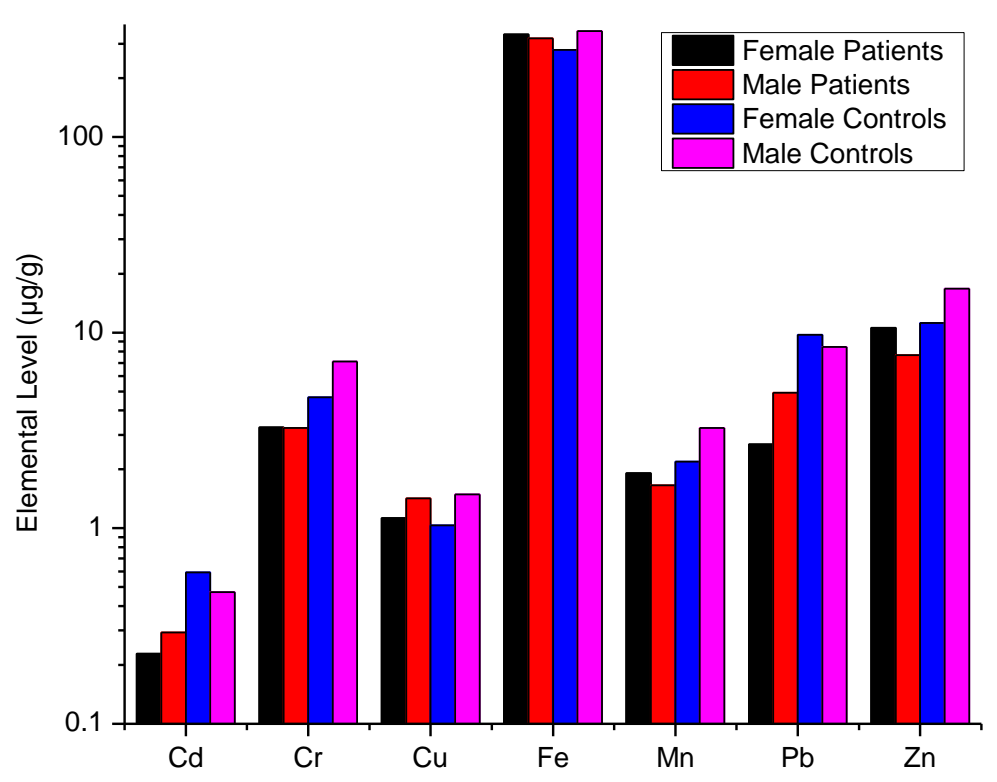

(a)

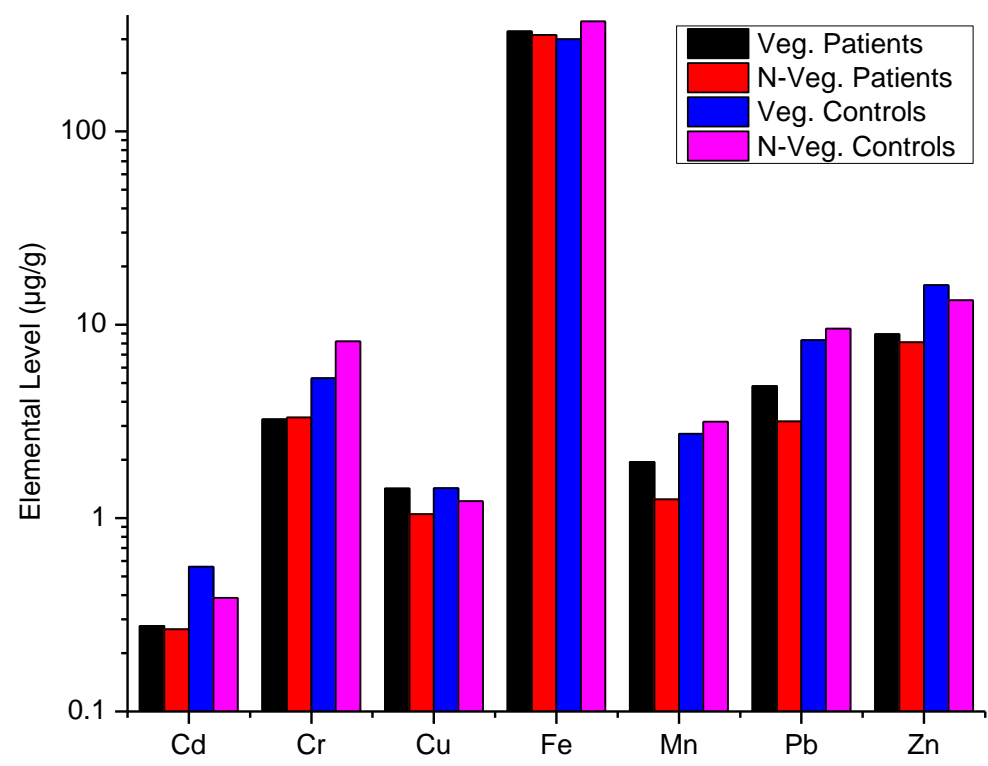

(b)

Figure 3. Comparative average concentrations of trace elements in the blood of gastric cancer patients and healthy subjects based on (a) gender; (b) food habits.

Comparative assessment of average levels of trace elements in the blood based on habitat of the subjects are shown in Figure 4(a), which revealed that relatively higher concentrations of $\mathrm{Cu}, \mathrm{Mn}, \mathrm{Pb}$, and $\mathrm{Zn}$ were found in the urban carcinoma patients compared to the rural carcinoma patients while only Cd exhibited relatively higher level in the rural patients. Nevertheless, average Fe concentration was found to be comparable in both urban and rural cancerous patients. In the case of controls, average concentrations of $\mathrm{Zn}$ and $\mathrm{Mn}$ were noted to be higher in the blood of rural controls than urban controls, whereas mean levels of $\mathrm{Pb}$ and $\mathrm{Cd}$ were comparatively higher in the controls residing in rural areas. Nonetheless, mean levels of $\mathrm{Cr}, \mathrm{Cu}$, and $\mathrm{Fe}$ were found to be nearly comparable in the blood of both rural and urban controls. 


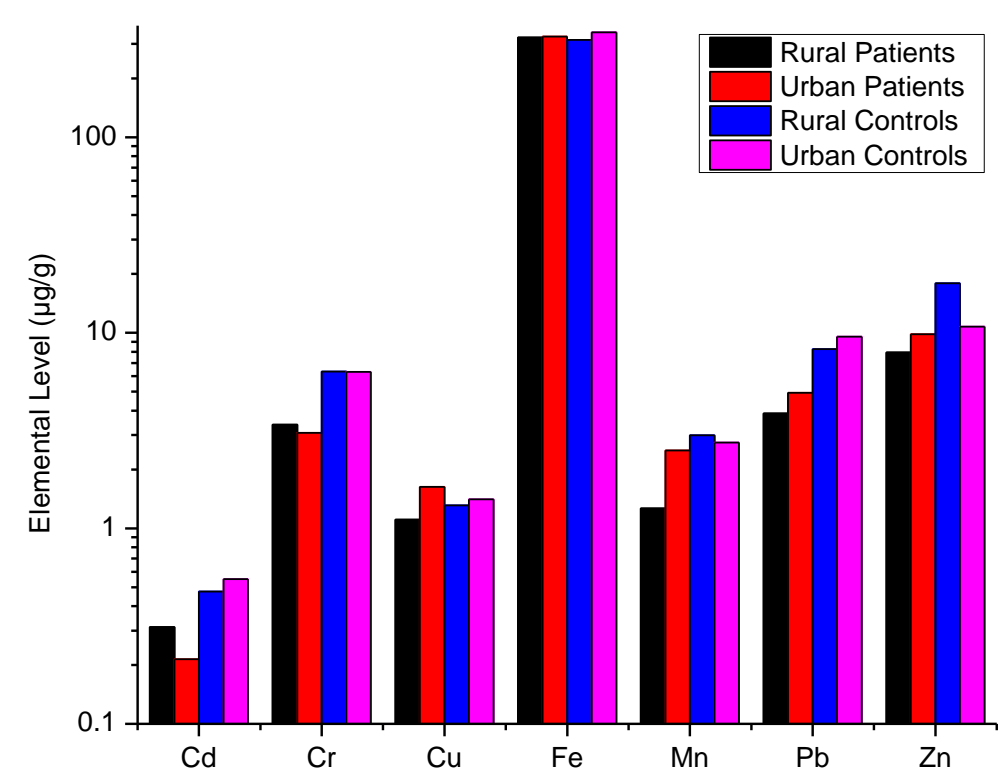

(a)

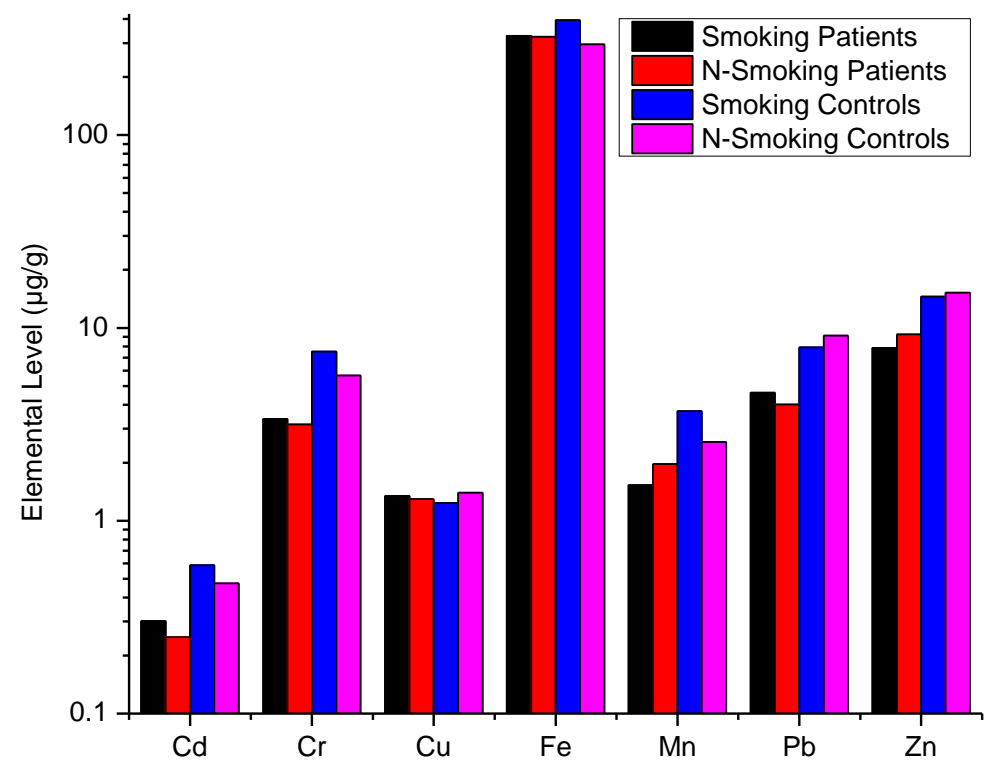

(b)

Figure 4. Comparative average concentrations of trace elements in the blood of gastric cancer patients and healthy subjects based on (a) habitat; (b) smoking habits.

Tobacco smoke contains some deadly carcinogenic chemicals; therefore, it has long been recognized as a chemical carcinogen. Accordingly, cigarette smoke is in the USEPA's Group-A and the IARC Group-1 classification for carcinogens. It is another recognized risk factor for gastric cancer [24, 27]. Tobacco smoking has been reported to cause about $60 \%$ and $20 \%$ increase in GC risk in men and women, respectively. It has been estimated that $18 \%$ of GC cases are attributable to tobacco smoking $[2,28]$. The incidence of GC consistently and significantly increased with smoking duration as well as cigarettes smoked per day [27]. Smoking-based comparison of selected trace elemental levels in the blood of the patients and controls is shown in Figure 4(b), which showed that relatively higher $\mathrm{Cd}$ and $\mathrm{Pb}$ concentrations were found in the blood of smoking patients than the non-smoking patients. In contrast, mean levels of $\mathrm{Mn}$ and $\mathrm{Zn}$ were observed to be considerably higher in the blood of non-smoking patients. It has been reported that $\mathrm{Cd}$ is emitted by all forms of tobacco and has been rated as a carcinogen in smoking (both active and passive). It is noted as one of the major sources of the human body [27]. Nevertheless, the average contents of $\mathrm{Cu}, \mathrm{Fe}$, and $\mathrm{Cr}$ were almost comparable 
in both smoking and non-smoking cancer patients. In the case of controls, mean levels of $\mathrm{Cr}$, $\mathrm{Cd}, \mathrm{Mn}$, and $\mathrm{Fe}$ showed relatively higher contributions in the blood of smoking healthy donors than non-smoking controls, while mean levels of $\mathrm{Zn}$ showed comparable contents in both donor groups. Moreover, the average concentrations of $\mathrm{Cu}$ and $\mathrm{Pb}$ were found to be noticeably higher in the blood of non-smoking controls.

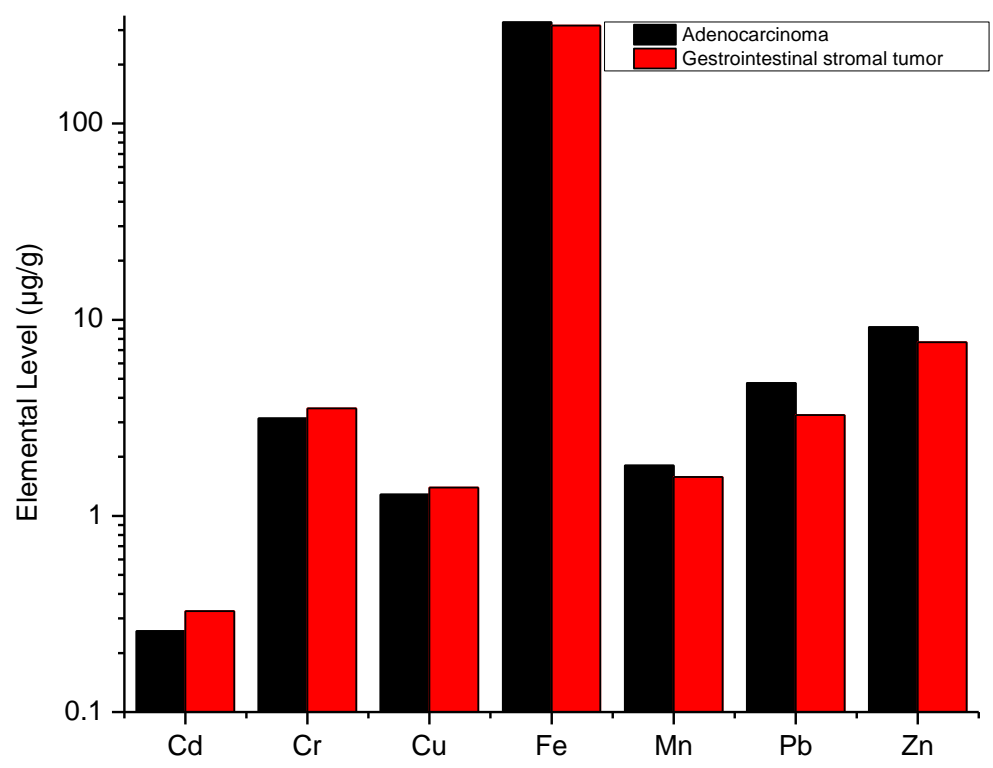

(a)

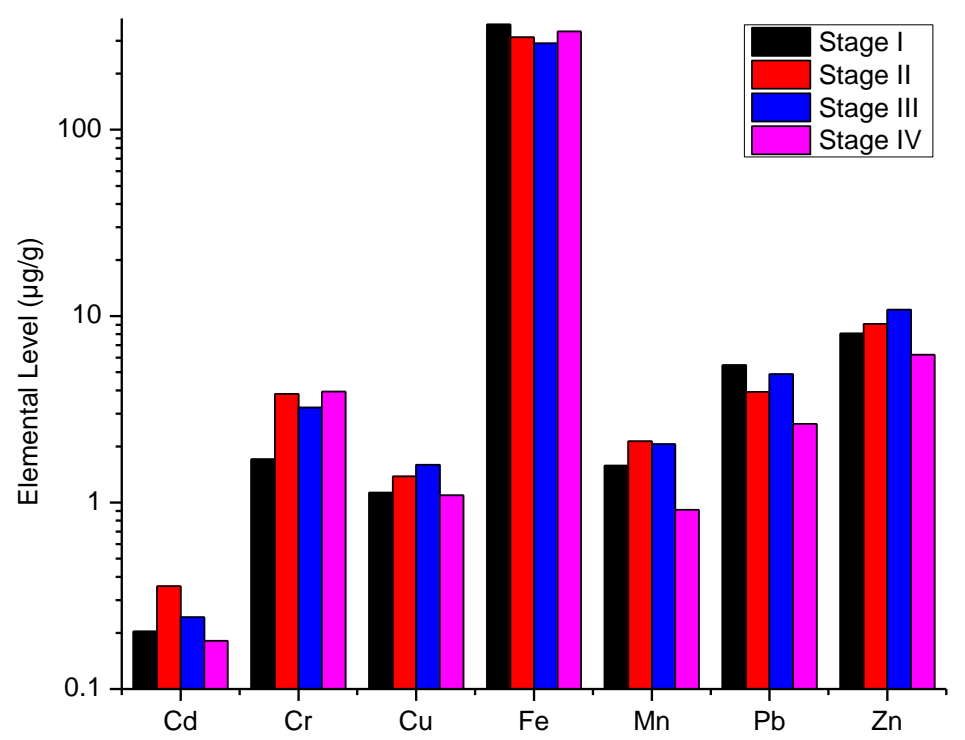

(b)

Figure 5. Comparative average concentrations of trace elements in the blood of gastric cancer patients based on (a) different types; (b) various stages.

\subsection{Comparison based on gastric cancer types and stages.}

A comparison of average elemental levels in cancer patients' blood based on different types (adenocarcinoma and gastrointestinal stromal tumor) is shown in Figure 5(a). A comparative study revealed that Cd's average concentration was rather higher in the blood of gastrointestinal stromal tumor patients. At the same time, elevated mean levels of $\mathrm{Mn}$ and $\mathrm{Pb}$ were found in the blood of adenocarcinoma patients. Nonetheless, average concentrations of $\mathrm{Fe}, \mathrm{Cu}, \mathrm{Cr}$, and $\mathrm{Zn}$ were found to be almost comparable in the blood of both types of GC patients. 
Gastric cancer patients are often diagnosed at advanced stages because of the lack of screening strategies, leaving most patients with limited treatment options [3]. A comparison of average elemental levels in GC patients' blood at different stages (stage-I, stage-II, stage-III, and stage-IV) is shown in Figure 5(b), which indicated that the average level of Cd was found to be higher at stage-II. However, elevated levels of $\mathrm{Cu}$ and $\mathrm{Zn}$ were found in the blood of patients at stage-III. In addition, the mean levels of $\mathrm{Fe}$ and $\mathrm{Pb}$ were noted to be higher in the blood of patients at stage-I. Nevertheless, the mean concentration of $\mathrm{Zn}$ was observed to be lowest in the blood samples with stage-IV of GC patients.

\subsection{Multivariate analysis.}

Another fascinating aspect of the present study was the multivariate apportionment of the elemental levels in gastric carcinoma patients' blood and controlled using PCA and CA. The PC loadings extracted using varimax-normalized rotation on the elemental dataset for the cancerous patients and healthy donors/controls are shown in Table 5. In the patients' case, the PCA of elemental data yielded 3 PCs with an eigenvalue greater than 1, commutatively explaining approximately $84.81 \%$ of the total variance of data (Table 5). The CA (based on Ward's method) of the elemental data pertaining to gastric carcinoma patients' blood is shown as a dendrogram in Figure 6(a). PC 1, which accounts for $36.48 \%$ of the variance, is characterized by higher loadings of $\mathrm{Cr}, \mathrm{Zn}, \mathrm{Pb}$, and $\mathrm{Fe}$ duly supported by strong clusters in $\mathrm{CA}$ as shown in Figure 6(a). These elements were mainly contributed by dietary sources and environmental contamination by anthropogenic sources. PC 2 comprised of $31.44 \%$ of the total variance showed maximum loadings for $\mathrm{Cu}$ and $\mathrm{Mn}$ with a similar cluster of these elements in CA. These elements were mainly linked with the nutritional habits of the patients. Similarly, the third PC with $16.88 \%$ of the total variance revealed maximum loading for $\mathrm{Cd}, \mathrm{Pb}$, and $\mathrm{Fe}$ and formed a joint cluster of these elements in cluster analysis. These elements were believed to be mainly contributed by the lifestyle of the patients as well as anthropogenic contamination and environmental pollution. It is generally considered that $\mathrm{Pb}, \mathrm{Cd}$, and $\mathrm{Cr}$ can trigger the oxidative stress in the body, which is an important cause to initiate the neoplasm in the stomach $[29,30]$. Cluster analysis confirmed that toxic trace elements share communal clusters with the essential elements supporting the cancerous patients' imbalances.

Table 5. Principal component loadings of trace elements in the blood of gastric cancer patients and healthy subjects.

\begin{tabular}{l|c|c|c|c|c}
\multirow{2}{*}{} & \multicolumn{3}{|c}{ Patients } & \multicolumn{2}{c}{ Healthy Subjects } \\
\cline { 2 - 6 } & PC 1 & PC 2 & PC 3 & PC 1 & PC 2 \\
\hline Eigen value & 2.554 & 2.201 & 1.182 & 2.666 & 2.104 \\
\hline Total Variance (\%) & 36.48 & 31.44 & 16.88 & 38.09 & 30.06 \\
\hline Cumulative Variance (\%) & 36.48 & 67.92 & 84.81 & 38.09 & 68.15 \\
\hline $\mathrm{Cd}$ & - & - & 0.949 & 0.651 & - \\
\hline $\mathrm{Cr}$ & 0.889 & - & - & 0.748 & - \\
\hline $\mathrm{Cu}$ & - & 0.958 & - & - & 0.974 \\
\hline $\mathrm{Fe}$ & 0.598 & -- & 0.422 & 0.819 & - \\
\hline $\mathrm{Mn}$ & - & 0.934 & - & - & 0.898 \\
\hline $\mathrm{Pb}$ & 0.636 & - & 0.475 & 0.598 & - \\
\hline $\mathrm{Zn}$ & 0.847 & 0.302 & - & 0.767 & 0.290
\end{tabular}

In the case of controls, PCA of the elemental data yielded two major PCs with eigenvalue $>1$, commutatively explaining approximately $68.15 \%$ of the total variance of data (Table 5). The CA of elemental data pertaining to the blood of controls based on Wards' method is portrayed as a dendrogram in Figure 6(b). PC 1 manifested dominant loadings for 
$\mathrm{Pb}, \mathrm{Fe}, \mathrm{Zn} \mathrm{Cd}$, and $\mathrm{Cr}$, which shared common clusters in $\mathrm{CA}$. These elements were mostly originated from mixed sources consisting of food habits as well as significantly influenced by anthropogenic pollution. The second PC indicated a higher buildup of $\mathrm{Cu}$ and $\mathrm{Mn}$, which shared a common cluster in CA. These elements were mostly regulated by internal body metabolism in healthy donors. Overall, CA and PCA revealed mutual associations of toxic and essential elements in cancerous patients. Such associations may be attributed to initiating this malignancy in stomach cancer patients.

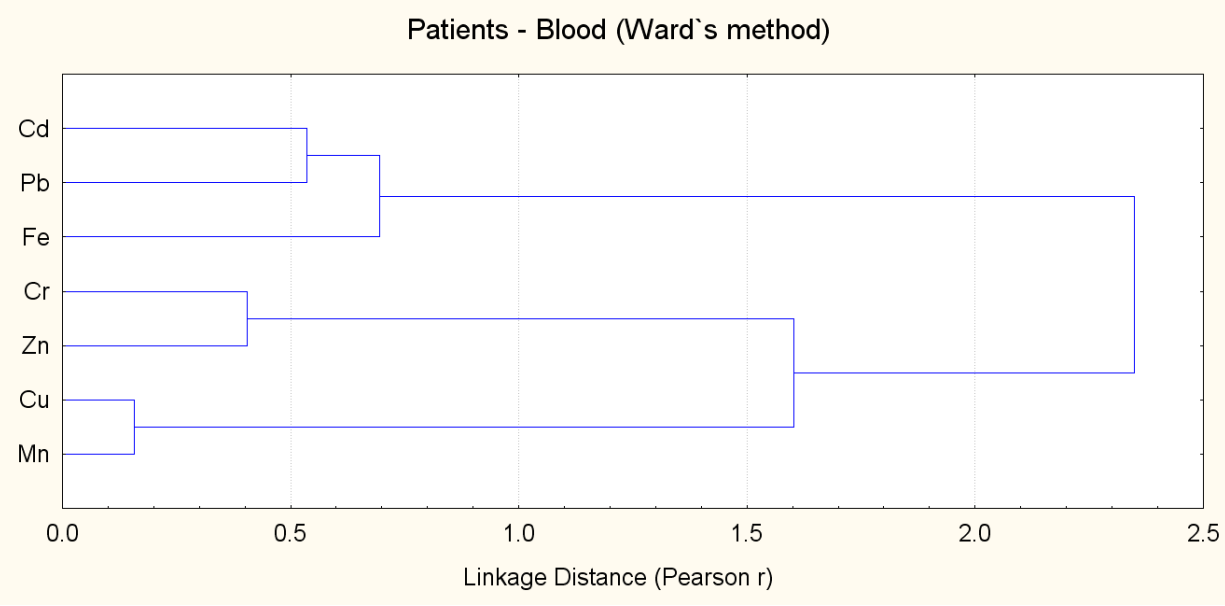

(a)

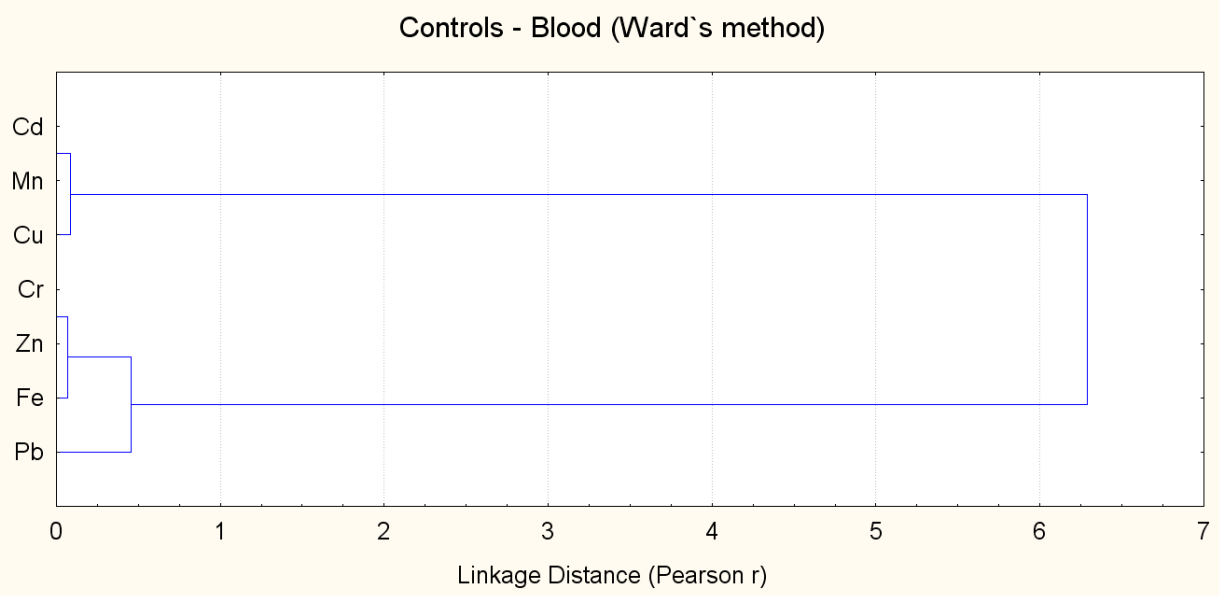

(b)

Figure 6. Cluster analysis of trace elements in the blood of (a) gastric cancer patients; (b) healthy subjects.

\subsection{Trace elements, oxidative stress, and gastric cancer.}

The stomach is a sensitive digestive organ, and oxidative stress is a strong pathogenic co-factor involved in developing diseases, including stomach cancer [31]. Environmental stressors, such as toxic elements are considered to induce oxidative stress and alter the cellular redox balance [32]. Oxidative stress arises from excessive production of reactive oxygen species (ROS) or a decline in antioxidant defenses, resulting in the pathogenesis of gastric inflammation and ulcerogenic [32, 33]. Further, it can damage DNA in stomach epithelial cells, supporting its association with gastric carcinogenesis [18]. Most of the carcinogenic elements produce ROS via the Fenton reaction of superoxide anion radical and hydroxyl radical, eventually resulting in damages cellular macromolecules like DNA, RNA, proteins, lipids, and alteration of cell homeostasis [18, 33, 34], although the exact mechanism of the action of the trace elements is not yet clear. However, the mechanisms concerned in toxic element mediated 
carcinogenesis resulting from oxidative stress may cause genetic and epigenetic changes, uncontrolled cell growth, and abnormal cellular signaling [29]. Recent research suggested that ROS could be excessively formed in chronic diseases of the gastrointestinal tract and toxic to normal cells, contributing to the increased risk of cancer [35]. Ma and his colleagues obtained the results and confirmed that oxidative stress is involved in stomach cancer. They also found that stomach cancer patients had high levels of protein oxidation and DNA damage than control subjects [31]. Various studies have established the relationship between exposure to toxic elements or their compounds and the risk of developing gastric carcinoma. Some of the toxic elements (including $\mathrm{Cd}, \mathrm{Pb}$, and $\mathrm{Cr}$ ) are clearly classified as human carcinogens [13-15, 18, 36]. The physiological role of some trace elements in the prevalence/prevention of gastric malignancy in humans is discussed below.

For living organisms, $\mathrm{Pb}$ interrupts enzyme activation, inhibits mineral absorption, stops structural protein synthesis, and lowers the availability of sulfhydryl antioxidant [37, 38]. It can cause damage to the mitochondrial, apoptosis, and intracellular depletion of glutathione [39]. Evidence supported that $\mathrm{Pb}$ causes damage to DNA by the production of ROS, which initiates DNA oxidation and subsequent damage [30]. Further, $\mathrm{Pb}$ has an adverse effect on $\mathrm{Fe}$ deficiency, which increases the absorption of $\mathrm{Pb}$ [40]. In mice, Ca homeostasis is altered on exposure to $\mathrm{Pb}$ [41]. It has recently been reported that $\mathrm{Pb}$ can promote tumorigenesis by inducing interleukin-8 expression in gastric cancer AGS cells [37]. Higher $\mathrm{Pb}$ level was found in normal tissue when compared to gastric cancer tissue [36]. Exposure to $\mathrm{Pb}$ reported in workers in a $\mathrm{Pb}$ smelter at workplaces has been associated with a risk of GC, but it has not been definitely concluded to be carcinogenic in humans [42, 43].

Zinc regulates key cellular functions, including response to oxidative stress, DNA replication, DNA damage repair, cell cycle progression, and apoptosis [44, 45]. It may inhibit the production of free radicals, reduce the frequency of harmful gene mutations, and ultimately provide defense against cancer initiation and progression [46, 47]. It means $\mathrm{Zn}$ has masking capacity, thus inhibiting tumor growth. Some epidemiologic studies investigated the relationship between $\mathrm{Zn}$ intake and risk of GC $[45,48]$. However, the results were inconsistent; for instance, some studies suggested that higher $\mathrm{Zn}$ intake might increase GC risk, while other studies showed higher $\mathrm{Zn}$ intake was linked to reducing the risk [36, 45]. Ji et al. [44] reported that the serum Zn level was lower in advanced GC patients [14, 45]. Reddy and coworkers reported that Zn's level was lower significantly in the patients of GC tissue than in normal tissues $[18,43]$. In the present study, Zn's blood level was significantly reduced in GC group compared with healthy subjects; thus, it supported that the lower $\mathrm{Zn}$ levels were linked with increased risk of GC [48].

Cadmium can generate free radicals and ultimately enhances protein and DNA oxidation in cells, leading to DNA damage and tumor growth in addition to its ability to interfere with cell signaling $[2,49,50]$. Cadmium possessed the ability to replace $\mathrm{Cu}$ and $\mathrm{Fe}$ in various cytoplasmic and membrane proteins. An increase in unbound free $\mathrm{Fe}$ and $\mathrm{Cu}$ participates in oxidative stress through the Fenton reaction [36, 50, 51]. Cadmium can displace $\mathrm{Ca}$, thereby affecting the function of E-cadherin and disrupting cell junctions [18]. In this manner, the gastric mucosal barrier is disrupted due to decreased mucus thickness, mucous content, and basal acid output and increased lipid peroxidation products [38]. Cadmium exposure resulted in the formation of dysplastic lesions in the gastric glandular epithelium [52]. Cadmium-induced changes in the gastric mucosa can disrupt the gastric barrier and increase ulceration risk [49]. Ostadrahimi et al. [2] reported a higher blood Cd level in gastrointestinal 
cancer than controls. Based on epidemiological studies, $\mathrm{Cd}$ seems to be associated with overall cancer mortality, including lung, pancreatic, non-Hodgkin lymphoma, and leukemia, ovarian, and uterine cancers [2].

Chromium can induce a wide variety of DNA lesions inside the cell, including Cr-DNA adduct, which causes mutations and chromosomal breaks, DNA protein cross-links, and oxidative damage [53]. Carcinogenicity of $\mathrm{Cr}$ includes direct DNA damage mutation, genomic instability, aneuploidy, and cell transformation $[53,54]$. Several studies suggested that $\mathrm{Cr}$ may also have carcinogenic effects in other internal organs, including the GC [55, 56]. In vitro studies have revealed that $\mathrm{Cr}$-induced mutations can be generated through different types of DNA damage such as inter-strand cross-links, DNA-protein cross-links, and DNA adducts [51, 57]. It has been reported that $\mathrm{Cr}$ can induce DNA lesions in peripheral blood lymphocytes and human gastric mucosa cells partly due to direct contact between $\mathrm{Cr}$ and stomach mucosa [58]. Beaumont et al. [59] reported an increase in stomach cancer among villagers exposed to $\mathrm{Cr}$ in drinking water. Chromium levels seem to be higher in the stomach's cancer tissue than those of normal tissue, which supports its carcinogenic property [36].

Copper facilitates ROS formation that can damage biomolecules, including DNA and chromatin, and causes various kinds of damage to DNA [60, 61]. It is involved in the initiation and promotion of carcinogenesis by the generation of free radicals and in the progression of tumor growth through angiogenesis in tumor cells [62]. Abnormally high serum $\mathrm{Cu}$ levels are found in patients with many types of progressive tumors, making $\mathrm{Cu}$ an obligatory co-factor in the angiogenesis process [36]. A high concentration of $\mathrm{Cu}$ could induce growth proliferation and cancer, whereby highly reactive oxygen species are generated, which produce hydroxyl radicals that adversely modify proteins, lipids, and nucleic acids [62]. Many studies have shown higher $\mathrm{Cu}$ levels in both serum and tumor tissues in GC patients compared to their healthy counterparts $[18,62]$. Its deficiency may increase cellular susceptibility to oxidative damage [60]. Reddy and coworkers [43] have reported significant decreases in $\mathrm{Cu}$ concentrations in gastric tumor tissues than normal samples. Bhat [14] found elevated Cu levels in the serum of malign stomach patients than in normal donors. A significant decrease in the $\mathrm{Cu}$ concentration was found in GC tissue than normal tissue [36].

Iron plays an important role during inflammation and the immune response to infection [63]. Both Fe deficiency and overload are harmful and can contribute to disease development in several ways [64, 65]. Abnormal accumulation of Fe and subsequent excess ROS causes oxidative stress, which incurs damage to DNA, proteins, lipids, or other biomolecules and even results in cell death [66]. There is definitive evidence that Fe overload induces oxidative stress and DNA strand breaks, inactivate enzymes, depolymerize polysaccharides, initiate lipid peroxidation damage, which can enhance carcinogenic risk and ultimately accelerate tumor initiation [63]. Iron-overload disorder hemochromatosis is associated with an increased risk of GC $[15,64]$. On the contrary, Fe deficiency also increases oxidative stress and DNA damage, which might increase carcinogenesis risk, especially in the gastrointestinal tract. Some epidemiological studies have indicated an increased risk of gastrointestinal tumors among individuals with low Fe intake. In vivo data from rodent cancer models indicates the early progression of gastrointestinal tumors during iron deficiency [15]. However, marked $\mathrm{Fe}$ deficiency was observed in the tissue of carcinoma stomach than in the normal stomach tissue $[15,64]$. Reddy and coworkers have reported a significantly low Fe in GC tissue than normal tissue $[36,43]$. Case-control studies have demonstrated an inverse relationship between dietary Fe intake and gastric adenocarcinoma [63]. In rats, Fe deficiency accelerates carcinogen- 
induced gastrointestinal cancer and metastasis [67]. In the present study, the concentration of Fe was lower in GC patients than healthy donors. These results suggested that further investigation is needed to clarify the role of iron in gastric carcinogenesis.

Manganese is essential for the normal immune system, blood sugar regulation, cellular energy, reproduction, and digestion [68]. High intracellular Mn can compensate for superoxide dismutase loss and protect against oxidative stress [68]. Manganese also interferes with $\mathrm{Ca}$ homeostasis in mitochondria by inhibiting its efflux. Furthermore, DNA strand breakage at a low Mn level was reported [69]. A study found that the Mn level in GC tissue is lower than those in normal tissue [36]. The observed low level of $\mathrm{Mn}$ in the cancer tissue may inhibit the formation of cancer-protective antigens in correlation with the observation of Reddy et al. [43]. A Low Mn level in the blood of GC patients than controls was also found in the present study (Table 3).

In the present study, elemental levels were assessed in relation to various clinical types and stages of the stomach cancer patients for detailed comparison. Certainly, there are some limitations; firstly, data were evaluated at the population level, no conclusions can be drawn at the individual level; secondly, complete exposure history of the trace elements in the present study was not available; thirdly, lack of speciation of the elements in the data. A relatively small sample size of the study was another limitation. The etiology underlying the association can be complicated. It is still unknown whether elemental levels in the blood can be considered a likely cause of gastric cancer or vice versa.

\section{Conclusions}

The present study revealed that most of the elements exhibited significant differences in the distribution in gastric carcinoma patients' blood and healthy subjects. Mean levels of Fe and $\mathrm{Zn}$ were found to be lower in gastric cancer patients than healthy subjects. Average concentrations of $\mathrm{Cd}, \mathrm{Cr}, \mathrm{Mn}$, and $\mathrm{Pb}$ were found to be higher in the blood of controls than the patients. Most of the elements exhibited significant disparities in the patients' blood based on tumor types and stages. Gastrointestinal stromal tumor patients showed a higher average concentration of $\mathrm{Cd}$ while comparatively elevated levels of $\mathrm{Mn}$ and $\mathrm{Pb}$ contents were noted in the blood of adenocarcinoma patients. Among stages, the average level of $\mathrm{Cd}$ was found higher at stage-II, and elevated levels of $\mathrm{Cu}$ and $\mathrm{Zn}$ were found at stage-III in the cancerous patients. In addition, mean levels of $\mathrm{Fe}$ and $\mathrm{Pb}$ manifested elevated levels in patients' blood at stage-I. Nevertheless, the mean concentration of $\mathrm{Zn}$ was observed to be lowest at stage-IV in the blood sample of tumor patients. Correlation study displayed diverse associations among the trace elements in the malignant patients' blood and healthy subjects. Significant variations in the elemental levels were found with the habitat, gender, smoking habits, and donor groups' food habits. Multivariate study in terms of PCA and CA revealed significantly divergent sources/grouping and apportionment of the elements in the healthy subjects and cancer patients. It may be considered a diagnostic tool in clinical studies.

\section{Funding}

This research received no external funding. 


\section{Acknowledgments}

We are grateful to the Quaid-i-Azam University, Islamabad, Pakistan, for providing technical and financial assistance to undertake this study. We also acknowledge the administration of Nuclear Oncology \& Radiotherapy Institute (NORI), Islamabad, Pakistan, for their invaluable help during sample collection.

\section{Conflicts of Interest}

The authors declare no conflict of interest.

\section{References}

1. Fei, X.; Lou, Z.; Christakos, G.; Ren, Z.; Liu, Q.; Lv, X. The association between heavy metal soil pollution and stomach cancer: a case study in Hangzhou city, China. Environmental Geochemistry Health 2018, 40, 2481-2490, https://doi.org/10.1007/s10653-018-0113-0.

2. Ostadrahimi, A.; Payahoo, L.; Somi, M.H.; Hashemzade, S.H.; Esfahani, A.; Asgharijafarabadi, M.; Mobasseri, M.; Samadi, N.; Faraji, S.; KhajeBishak, Y. The association between blood cadmium levels and the risk of gastrointestinal cancer in Tabriz, northwest of Iran. Polish Annals of Medicine 2017, 24, 133137, http://dx.doi.org/10.1016/j.poamed.2016.05.004.

3. Martinson, H.A.; Mallari, D.; Richter, C.; Wu, T.T.; Tiesinga, J.; Alberts, S.R.; Olnes, M.J.; Molecular classification of gastric cancer among Alaska native people. Cancers 2020, 12, https://doi.org/10.3390/cancers12010198.

4. Eichelberger, L.; Murphy, G.; Etemadi, A.; Abnet, C.C.; Islami, F.; Shakeri, R.; Malekzadeh, R.; Dawsey, S.M. Risk of gastric cancer by water source: evidence from the golestan case-control study. PLoS One 2015, 10, https://doi.org/10.1371/journal.pone.0128491.

5. Shabbir, A.; Qureshi, M.A.; Khalid, A.B.; Mirza, T.; Shaikh, A.; Hasan, S.M. Gastric adenocarcinoma expressing human epidermal growth factor receptor in south Asian population. Saudi Journal of Gastroenterology 2018, 24, 289-293, https://doi.org/10.4103/sjg.SJG_23_18.

6. Shah, M.A.; Khanin, R.; Tang, L.; Janjigian, Y.Y.; Klimstra, D.S.; Gerdes, H.; Kelsen, D.P. Molecular classification of gastric cancer: a new paradigm. Clinical Cancer Research 2011, 17, 2693-2701, https://doi.org/10.1158/1078-0432.CCR-10-2203.

7. Nagini, S. Carcinoma of the stomach: a review of epidemiology, pathogenesis, molecular genetics and chemoprevention. World Journal of Gastrointestinal Oncology 2012, 4, 156-169, https://doi.org/10.4251/wjgo.v4.i7.156.

8. Yakirevich, E.; Resnick, M.B. Pathology of gastric cancer and its precursor lesions. Gastroenterology Clinics of North America 2013, 42, 261-284, https://doi.org/10.1016/j.gtc.2013.01.004.

9. Daniyal, M.; Ahmad, S.; Ahmad, M.; Asif, H.M.; Akram, M.; Rehman, S.; Sultana, S. Risk factors and epidemiology of gastric cancer in Pakistan. Asian Pacific Journal of Cancer Prevention 2015, 6, 4821-4824, http://dx.doi.org/10.7314/APJCP.2015.16.12.4821.

10. Rawla, P.; Barsouk, A. Epidemiology of gastric cancer: global trends, risk factors and prevention. Gastroenterology Review 2019, 14, 26-38, https://doi.org/10.5114/pg.2018.80001.

11. Zhuntova, G.V.; Azizova, T.V.; Grigoryeva, E.S. Risk of stomach cancer incidence in a cohort of Mayak PA workers occupationally exposed to ionizing radiation. PLoS ONE 2020, 15, https://doi.org/10.1371/journal.pone.0231531.

12. Idrees, R.; Fatima, S.; Ghafar, J.A.; Raheem, A.; Ahmad, Z. Cancer prevalence in Pakistan: meta-analysis of various published studies to determine variation in cancer figures resulting from marked population heterogeneity in different parts of the country. World Journal of Surgical Oncology 2018, 16, https://doi.org/10.1186/s12957-018-1429-z.

13. Hu, A.; Li, L.; Hu, C.; Zhang, D.; Wang, C.; Jiang, Y.; Zhang, M.; Liang, C.; Chen, W.; Bo, Q.; Zhao, Q. Serum concentrations of 15 elements among helicobacter pylori-infected residents from Lujiang county with high gastric cancer risk in eastern China. Biological Trace Element Research 2018, 186, 21-30, https://doi.org/10.1007/s12011-018-1283-4.

14. Bhat, S.A. The association between minerals and gastric cancer. Journal of Oncology Research Treatment 2017, 2 .

15. Kohzadi, S.; Sheikhesmaili, F.; Rahehagh, R.; Parhizgar, B.; Ghaderi, E.; Loqmani, H.; Shahmoradi, B.; Mohammadi, E.; Maleki, A. Evaluation of trace element concentration in cancerous and non-cancerous tissues of human stomach. Chemosphere 2017, 184, 747-752, http://doi.org/10.1016/j.Chemosphere.2017.06.071. 
16. Janbabai, G.; Alipour, A.; Ehteshami, S.; Borhani, S.S.; Farazmandfar, T. Investigation of trace elements in the hair and nail of patients with stomach cancer. Indian Journal of Clinical Biochemistry 2018, 33, 450455, https://doi.org/10.1007/s12291-017-0693-y.

17. Afzal, A.; Qayyum, M.A; Shah, M.H. Study of trace metal imbalances in the scalp hair of stomach cancer patients with different types and stages. Biological Trace Element Research 2019, 196, 365-374, https://doi.org/10.1007/s12011-019-01926-w.

18. Yuan, W.; Yang, N.; Li, X. Advances in understanding how heavy metal pollution triggers gastric cancer. BioMed Research International 2016, 2016, http://dx.doi.org/10.1155/2016/7825432.

19. Qayyum, M.A.; Shah, M.H. Disparities in the concentrations of essential/toxic elements in the blood and scalp hair of lymphoma patients and healthy subjects. Scientific Reports 2019, 9, https://doi.org/10.1038/s41598-019-51973-5.

20. StatSoft. STATISTICA for Windows. Computer Program Manual, StatSoft, Tulsa1 1999.

21. Qayyum, M.A.; Shah, M.H. Disparities in trace metal levels in Hodgkin/non-Hodgkin lymphoma patients in comparison with controls. Biological Trace Element Research 2019, 194, 34-47, https://doi.org/10.1007/s12011-019-01746-y.

22. Magalhaes, T.; Carvalho, M.L.; Bohlen, A.V.; Becker, M. Study on trace elements behaviour in cancerous and healthy tissues of colon, breast and stomach: Total reflection X-ray fluorescence applications. Spectrochimica Acta Part B 2010, 65, 493-498, https://doi.org/10.1016/j.sab.2010.04.001.

23. Edge, S.B.; Byrd, D.R.; Compton, C.C.; Fritz, A.G.; Greene, F.L.; Trotti, A. AJCC cancer staging manual. $7^{\text {th }}$ ed. New York, NY: Springer, 2010.

24. Butt, J.; Varga, M.G.; Wang, T.; Tsugane, S.; Shimazu, T.; Zheng, W.; Abnet, C.C.; Yoo, K.Y.; Park, S.K.; Kim, J.; Jee, S.H.; Qiao, Y.; Shu, X.O.; Waterboer, T.; Pawlita, M.; Epplein, M. Smoking, helicobacter pylori serology, and gastric cancer risk in prospective studies from China, Japan, and Korea. Cancer Prevention Research 2019, 12, 667-674, https://doi.org/10.1158/1940-6207.CAPR-19-0238.

25. Han, J.; Jiang, Y.; Liu, X.; Meng, Q.; Xi, Q.; Zhuang, Q.; Han, Y.; Gao, Y.; Ding, Q.; Wu, G. Dietary fat intake and risk of gastric cancer: a meta-analysis of observational studies. PLoS ONE 2015, 10, https://doi.org/10.1371/journal.pone.0138580.

26. Wang, Q.; Chen, Y.; Wang, X.; Gong, G.; Li, G.; Li, C. Consumption of fruit, but not vegetables, may reduce risk of gastric cancer: results from a meta-analysis of cohort studies. European Journal of Cancer 2014, 50, 1498-1509, http://dx.doi.org/10.1016/j.ejca.2014.02.009.

27. Li, W.Y.; Han, Y.; Xu, H.M.; Wang, Z.N.; Xu, Y.Y.; Song, Y.X.; Xu, H.; Yin, S.C.; Liu, X.Y.; Miao, Z.F. Smoking status and subsequent gastric cancer risk in men compared with women: a meta-analysis of prospective observational studies. BMC Cancer 2019, 19, https://doi.org/10.1186/s12885-019-5601-9.

28. Marques-Lespier, J.M.; Gonzalez-Pons, M.; Cruz-Correa, M. Current perspectives on gastric cancer. Gastroenterology Clinics of North America 2016, 45, 413-428, http://dx.doi.org/10.1016/j.gtc.2016.04.002.

29. Chen, Q.Y.; Marais, T.D.; Costa, M. Metals and mechanisms of carcinogenesis. Annual Review of Pharmacology and Toxicology 2019, 59, 537-554, https://dx.doi.org/10.1146\%2Fannurev-pharmtox010818-021031.

30. Lopes, A.C.B.A.; Peixe, T.; Mesas, A.E.; Paoliello, M.M.B. Lead exposure and oxidative stress: a systematic review. Reviews of environmental contamination and toxicology Preface 2015, 236, 193-238, https://doi.org/10.1007/978-3-319-20013-2_3.

31. Ma, Y.; Zhang, L.; Rong, S.; Qu, H.; Zhang, Y.; Chang, D.; Pan, H.; Wang, W. Relation between gastric cancer and protein oxidation, DNA damage, and lipid peroxidation. Oxidative Medicine and Cellular Longevity 2013, 2013, http://dx.doi.org/10.1155/2013/543760.

32. Aggarwal, V.; Tuli, H.S.; Varol, A.G.; Thakral, F.; Yerer, M.B.; Sak, K.; Varol, M.; Jain, A.; Khan, M.A.; Seth, G. Role of reactive oxygen species in cancer progression: molecular mechanisms and recent advancements. Biomolecules 2019, 9, https://doi.org/10.3390/biom9110735.

33. Valko, M.; Jomova, K.; Rhodes, C.J.; Kuca, K.; Musielk, K. Redox- and non-redox-metal-induced formation of free radicals and their role in human disease. Archives of Toxicology 2016, 90, 1-37, https://doi.org/10.1007/s00204-015-1579-5.

34. Bhattacharyya, A.; Chattopadhyay, R.; Mitra, S.; Crowe, S.E. Oxidative stress: an essential factor in the pathogensis of gastrointestinal mucosal diseases. Physiological Reviews 2014, 94, 329-354, https://doi.org/10.1152/physrev.00040.2012.

35. Lin, Y.; Kikuchi, S.; Obata, Y.; Yagyu, Y. Serum copper/zinc superoxide dismutase (Cu/Zn SOD) and gastric cancer risk: a case-control study. Japanese Journal of Cancer Research 2002, 93, 1071-1075.

36. Mulware, S.J. Comparative trace elemental analysis in cancerous and noncancerous human tissues using PIXE. Journal of Biophysics 2013, 2013.

37. Park, W.J; Kim, S.H; Kang, W.Y.; Ahn, J.S; Cho, S.; Lim, D.Y; Kim, S.; Moon, J. Blood lead level and Helicobacter pylori infection in a healthy population: a cross-sectional study. Archives of Environmental \& Occupational Health 2019, 75, 1-6, https://doi.org/10.1080/19338244.2019.1654969.

38. Charkiewicz, A.E.; Backstrand, J.R. Lead toxicity and pollution in Poland. International Journal of Environmental Research and Public Health 2020, 17, http://dx.doi.org/10.3390/ijerph17124385. 
39. Patrick, L. Lead toxicity part II: the role of free radical damage and the use of antioxidants in the pathology and treatment of lead toxicity. Alternative Medicine Review 2006, 11, 114-127,

40. Kwong, W.T. Friello, P.; Semba, R.D. Interactions between iron deficiency and lead poisoning: epidemiology and pathogenesis. Science of the Total Environment 2004, 330, 21-37, https://doi.org/10.1016/j.scitotenv.2004.03.017.

41. Fioresi, M.; Simoes, M.R.; Furieri, L.B.; Broseghini-Filho, G.B.; Vescovi, M.V.A.; Stefanon, I.; Vassallo, D.V. Chronic lead exposure increases blood pressure and myocardial contractility in rats. PLoS ONE 2014, 9, https://doi.org/10.1371/journal.pone.0096900.

42. Liao, L.M.; Friesen, M.C.; Xiang, Y.B.; Cai, H.; Koh, D.H.; Ji, B.T; Yang, G.; Li, HL.; Locke, S.J.; Rothman, N.; Zheng, W.; Gao. Y.T.; Shu, X.O.; Purdue, M.P. Occupational lead exposure and associations with selected cancers: the Shanghai men's and women's health study cohorts. Environmental Health Perspectives 2016, 124, 96-103, http://dx.doi.org/10.1289/ehp.1408171.

43. Reddy, S.B.; Charles, M.J.; Raju, G.J.N.; Vijayan, V.; Reddy, B.S.; Kumar, M.R.; Sundareswar, B. Trace elemental analysis of carcinoma kidney and stomach by PIXE method. Nuclear Instruments and Methods in Physics Research B 2003, 207, 345-355, https://doi.org/10.1016/S0168-583X(03)00463-4.

44. Ji, J.H.; Shin, D.G.; Kwon, Y.; Cho, D.H.; Lee, K.B.; Park, S.S.; Yoon, J. Clinical correlation between gastric cancer type and serum selenium and zinc levels. Journal of Gastric Cancer 2012, 12, 217-222, https://doi.org/10.5230/jgc.2012.12.4.217.

45. Khayyatzadeh, S.S.; Maghsoudi, Z.; Foroughi, M.; Askari, G.; Ghiasvand, R. Dietary intake of zinc, serum levels of zinc and risk of gastric cancer: a review of studies. Advanced Biomedicla Research 2015, 4.

46. Ho, E. Zinc deficiency, DNA damage and cancer risk. The Journal of Nutritional Biochemistry 2004, 15, 572-578, https://doi.org/10.1016/j.jnutbio.2004.07.005.

47. Skrajnowska, D.; Bobrowska-Korczak, B. Role of zinc in immune system and anti-cancer defense mechanisms. Nutrients 2019, 11, https://doi.org/10.3390/nu11102273.

48. Zhang, W.H.; Wu, X.J.; Niu, J.X.; Yan, H.; Wang, X.Z.; Yin, X.D.; Pang, Y. Serum zinc status and Helicobacter pylori infection in gastric disease patients. Asian Pacific Journal of Cancer Prevention 2012, 13, 5043-5046, http://dx.doi.org/10.7314/APJCP.2012.13.10.5043.

49. Genchi, G.; Sinicropi, M.S.; Lauria, G.; Carocci, C.; Catalano, A. The effects of cadmium toxicity. International Journal of Environmental Research and Public Health 2020, 17, https://doi.org/10.3390/ijerph17113782.

50. Fatima, G.; Raza, A.M.; Hadi, N.; Nigam, N.; Mahdi, A.A. Cadmium in human diseases: it's more than just a mere metal. Indian Journal of Clinical Biochemistry 2019, 34, 371-378, https://doi.org/10.1007/s12291019-00839-8.

51. Jomova, K.; Valko, M. Advances in metal-induced oxidative stress and human disease. Toxicology 2011, 283, 65-87, https://doi.org/10.1016/j.tox.2011.03.001.

52. Wallace, D.R.; Taalab, Y.M.; Heinze, S.; Lovakovic, B.T.; Pizent, A.; Renieri, E.; Tsatsakis, A.; Farooqi, A.A.; Javorac, D.; Andjelkovic, M.; Bulat, Z.; Antonijevic, B.; Djordjevic, A.B. Toxic-metal-induced alteration in miRNA expression profile as a proposed mechanism for disease development. Cells 2020, 9 , https://doi.org/10.3390/cells9040901.

53. Deng, Y.; Wang, M.; Tian, T.; Lin, S.; Xu, P.; Zhou, L.; Dai, C.; Hao, Q.; Wu, Y.; Zhai, Z.; Zhu, Y.; Zhuang, G.; Dai, Z. The effect of hexavalent chromium on the incidence and mortality of human cancers: a metaanalysis based on published epidemiological cohort studies. Frontiers in Oncology 2019, 9, https://doi.org/10.3389/fonc.2019.00024.

54. Gatto, N.M.; Kelsh, A.M.; Mai, D.H.; Suh, M.; Proctor, D.M. Occupational exposure to hexavalent chromium and cancers of the gastrointestinal tract, a meta-analysis. Cancer Epidemiology 2010, 34, 388399, https://doi.org/10.1016/j.canep.2010.03.013.

55. Suh, M.; Wikoff, D.; Lipworth, L.; Goodman, M.; Fitch, S.; Mittal, L.; Ring, C.; Proctor, D. Hexavalent chromium and stomach cancer: a systematic review and meta-analysis. Critical Reviews in Toxicology 2019, 49, 140-159, https://doi.org/10.1080/10408444.2019.1578730.

56. Wang, Y.; Su, H.; Gu, Y.; Song, X.; Zhao, J. Carcinogenicity of chromium and chemoprevention: a brief update. OncoTargets and Therapy 2017, 10, 4065-4079, https://doi.org/10.2147/OTT.S139262.

57. Welling, R.; Beaumont, J.J.; Petersen, S.J.; Alexeeff, J.V.; Steinmaus, C. Chromium VI and stomach cancer: a metaanalysis of the current epidemiological evidence. Occupational and Environmental Medicine 2015, 72, 151-159, http://dx.doi.org/10.1136/oemed-2014-102178.

58. Trzeciak, A.; Kowalik, J.; Małecka-Panas, E.; Drzewoski J.; Wojewodzja, M.; Iwanenko, T.; Blasiak, J. Genotoxicity of chromium in human gastric mucosa cells and peripheral blood lymphocytes evaluated by the single cell gel electrophoresis (comet assay). Medical Science Monitor 2000, 6, 24-29.

59. Beaumont, J.J.; Sedman, R.M.; Reynolds, S.D.; Sherman, C.D.; Li, L.H.; Howd, R.A.; Sandy, M.S.; Zeise, L.; Alexeeff, G.V. Cancer mortality in a Chinese population exposed to hexavalent chromium in drinking water. Epidemiology 2008, 19, 12-23.

60. Linder, M.C. The relationship of copper to DNA damage and damage prevention in humans. Mutation Research 2012, 733, 83-91, http://dx.doi.org/10.1016/j.mrfmmm.2012.03.010. 
61. Lin, Y.; Wu, C.; Yan, W.; Guo, S.; Liu, B. Five serum trace elements associated with risk of cardia and noncardia gastric cancer in a matched case-control study. Cancer Management and Research 2020, 12, 4441-4451, https://doi.org/10.2147/CMAR.S250592.

62. Gupte, A.; Mumper, R.J. Elevated copper and oxidative stress in cancer cells as a target for cancer treatment. Cancer Treatment Reviews 2009, 35, 32-46, https://doi.org/10.1016/j.ctrv.2008.07.004.

63. Fonseca-Nunes, A.; Agudo, A.; Aranda, N.; Arija, V.; Cross, A.J.; Molina, E.; Sanchez, M.J.; Bueno-deMesquita, H.B.; Siersema, P.; Weiderpass, E.; Krogh, V.; Mattiello, A.; Tumino, R.; Saieva, C.; Naccarati, A.; Ohlsson, B.; Sjöberg, K.; Boutron-Ruault, M.C.; Cadeau, C.; Fagherazzi, G.; Boeing, H.; Steffen, A.; Kühn, T.; Katzke, V.; Tjønneland, A.; Olsen, A.; Khaw, K.T.; Wareham, N.; Key, T.; Lu, Y.; Riboli, E.; Peeters, P.H.; Gavrila, D.; Dorronsoro, M.; Quirós, J.R.; Barricarte, A.; Jenab, M.; Zamora-Ros, R.; Freisling, H.; Trichopoulou, A.; Lagiou, P.; Bamia, C.; Jakszyn, P. Body iron status and gastric cancer risk in the EURGAST study. International Journal of Cancer 2015, 137, 2904-2914, https://doi.org/10.1002/ijc.29669.

64. Pra, D.; Franke, S.I.R; Henriques, J.A.P.; Fenech, M. A possible link between iron deficiency and gastrointestinal carcinogenesis. Nutrition and Cancer 2009, 61, 415-426, https://doi.org/10.1080/01635580902803701.

65. Torti, S.V.; Torti, F.M. Iron: the cancer connection. Molecular Aspects of Medicine 2020, 75, https://doi.org/10.1016/j.mam.2020.100860.

66. Wang, F.; Lv, H.; Zhao, B.; Zhou, L.; Wang, S.; Luo, J.; Liu, J.; Shang, P. Iron and leukemia: new insights for future treatments. Journal of Experimental \& Clinical Cancer Research 2019, 38, https://doi.org/10.1186/s13046-019-1397-3.

67. Noto, J.M.; Gaddy, J.A.; Lee, J.Y.; Piazuelo, M.B.; Friedman, D.B.; Colvin, D.C.; Romero-Gallo, J.; Suarez, G.; Loh, J.; Slaughter, J.C.; Tan, S.; Morgan, D.R.; Wilson, K.T.; Bravo, L.E.; Correa, P.; Cover, T.L.; Amieva, M.R.; Peek, R.M., Jr. Iron deficiency accelerates Helicobacter pylori-induced carcinogenesis in rodents and humans. The Journal of Clinical Investigation 2013, 123, 479-492, https://doi.org/10.1172/JCI64373.

68. Li, L.; Yang, X. The essential element manganese, oxidative stress, and metabolic diseases: links and interactions. Oxidative Medicine and Cellular Longevity 2018, 2018, https://doi.org/10.1155/2018/7580707.

69. Avila, D.S.; Puntel, R.L.; Aschner, M. Manganese in health and disease. Metal Ions in Life Sciences 2013, 13, 199-227, https://doi.org/10.1007/978-94-007-7500-8_7. 